\title{
Study of Tourists Movement Pattern in Coastal Area and Small Islands, Makassar City
}

\author{
Sri Aliah Ekawati ${ }^{\mathrm{a}}$, Stevanny Manga ${ }^{\mathrm{b}}$, Fitha Rachmasari $^{\mathrm{b}}$, Febrika R.N $^{\mathrm{c}} *$ \\ ${ }^{a}$ Departemen Perencanaan Wilayah dan Kota, Universitas Hasanuddin, Makassar, Indonesia \\ ${ }^{b}$ Mahasiswa Departemen Perencanaan Wilayah dan Kota, Universitas Hasanuddin, Makassar, Indonesia \\ ${ }^{c}$ Mahasiswa Departemen Teknik Sipil, Universitas Hasanuddin, Makassar, Indonesia
}

\begin{abstract}
Makassar City is one of the coastal cities in Indonesia which has various tourist attractions. This tourist attraction is one of the interesting things considered by the people of Indonesia and even the world to visit Makassar City. This study aims to identify patterns of tourist movement in several coastal tourism areas and small islands in Makassar City. The method used in this research was qualitative method. Data obtained by searching secondary data, observation and distributing questionnaires online. Spatial analysis was done by interpreting the image map and digitizing it with ArcGIS, then analyzing the description. Through this research, it was known that there were three patterns of tourist movement, namely single point, base site and stop over. Based on these results, it is directed to develop a one-day trip tourism concept.
\end{abstract}

Keyword: Movement Patterns; Coastal Areas; Small Islands; Tourism; Makassar.

\section{Introduction}

Based on the World Tourism Organization in Tourism and Sustainable Development Goals - Travel to 2030, one of the investments to realize tourism is developing green infrastructure to improve transportation and to reduce air pollution. Tourism activities encourage infrastructure development and connectivity between regions and destinations (land, sea and air connectivity). Accessibility improvement, especially road networks in tourist areas, are expected to increase tourist visits (Widyastuti, et. al., 2019).

There are many regions in Indonesia that have natural and cultural beauty that are worth selling. However, poor accessibility results in low number of tourists being interested in visiting it (Ismardanto, 2017). Unbalanced tourist movements affect connectivity between one tourist destination and another, as well as the interaction of tourist destinations with the surrounding area (Widyastuti, et. al., 2019).

As a waterfront city, Makassar is dominated by nautical attractions. Most of tourist destination are located on coastal area and small islands. Those places create nodes that brings massive movements of people and vehicles. Therefore, some problems occure in Makassar City coastal area, such as: congestion on several roads, lack of alternative modes of transportation for tourist movements, and inadequate pedestrian and parking facilities (Wasilah and Hildayanti, 2019).

Based on accessibility problems that occur in coastal areas and small islands in Makassar City, this research was intended to increase regional productivity through patterns of tourist movement in coastal tourism areas and small islands in Makassar City. Research related to the patterns and motivations of tourist movements is needed as a benchmarking or a point of future infrastructure development in order to improve the accessibility of tourism in the coastal and small islands of Makassar City. The findings in the form of patterns and motivations for tourist movements were expected to be a reference for compiling appropriate recommendations to improve the connectivity of tourist attractions. Thus, it was expected that this research will

\footnotetext{
* Corresponding author. Sri Aliah Ekawati.

E-mail address: aliah.sriekawati@gmail.com.
} 
contribute to the area of regional and urban planning, especially in the planning of tourist areas on the coast and small islands.

\section{Method}

\subsection{Data collection technique and type of data}

This study used a descriptive qualitative and quantitative approach. Data collection includes literature review, observation, questionnaire, interview and documentation. Data collected consists of physical data such as tourist's attraction infrastructure in Makassar coastal area. Meanwhile the non-physical data includes socio-economic data and socio-cultural data, which consists of organizational forms that support tourism activities and potential or characteristic of each attraction that can be used as development instructions.

\subsection{Analysis Method}

This study used descriptive qualitative to frame the result of data interpretation through interviews and surveys in order to build a conclusion. To collect the data, some visitors at the tourist's attractions were interviewed as respondents. The respondents were randomly chosen or chose by the researchers if they meet the criteria determined by the researchers. Besides interview, spatial analysis is used to determine the pattern of tourist movements through attractions in coastal area and small islands in Makassar. This study was a qualitative research focused on data analysis after primary data collection in the field.

\section{Result and Discussion}

\subsection{Spatial Movement Pattern of Base Site}

The pattern of base site movement is the movement of tourists from the place of origin to one major tourist attraction, then proceed to one or several secondary destinations. Based on the data obtained, as many as $30 \%$ of respondents traveled in this pattern. Fort Rotterdam $(30.33 \%)$ and Losari Beach $(30 \%)$ were the main destinations for tourists before moving on to secondary attractions. The secondary attractions that become tourist destinations after visiting Fort Rotterdam and Losari Beach include: Somba Opu Street, Trans Studio Mall, Akkarena Beach and Tanjung Bayang Beach.

Based on data presented, the character of tourist objects with base site movement patterns can be identified. There was a similarity between the characters of each attraction, namely the dominance of activities that tend to be passive. These activities such as relaxing, enjoying natural scenery, culinary tours and shopping. As for Akkarena Beach and Tanjung Bayang Beach which had more challenging character of activity, this was the last destination for tourists. Based on the data it can also be seen that, in general, tourists moving with a base site pattern visit four attractions in one day. The average tourist spends one to three hours at each attraction.

Figure 1 shows the spatial movement of tourists with a base site pattern. Tourists start from Jalan Haji Bau then turn left onto Jalan Penghibur to reach the Losari Beach Pier. Furthermore, still down the Comforter Road to the north, tourists head for Fort Rotterdam. From Fort Rotterdam, tourists head south and enter Jalan Somba Opu. Tourists who wish to continue the journey to Trans Studio Mall can take the direction to the West (turn right from Jalan Somba Opu) to Jalan Datu Museng, Jalan Lamadukelleng, return to Jalan Haji Bau and enter Jalan Metro Tanjung Bunga. 


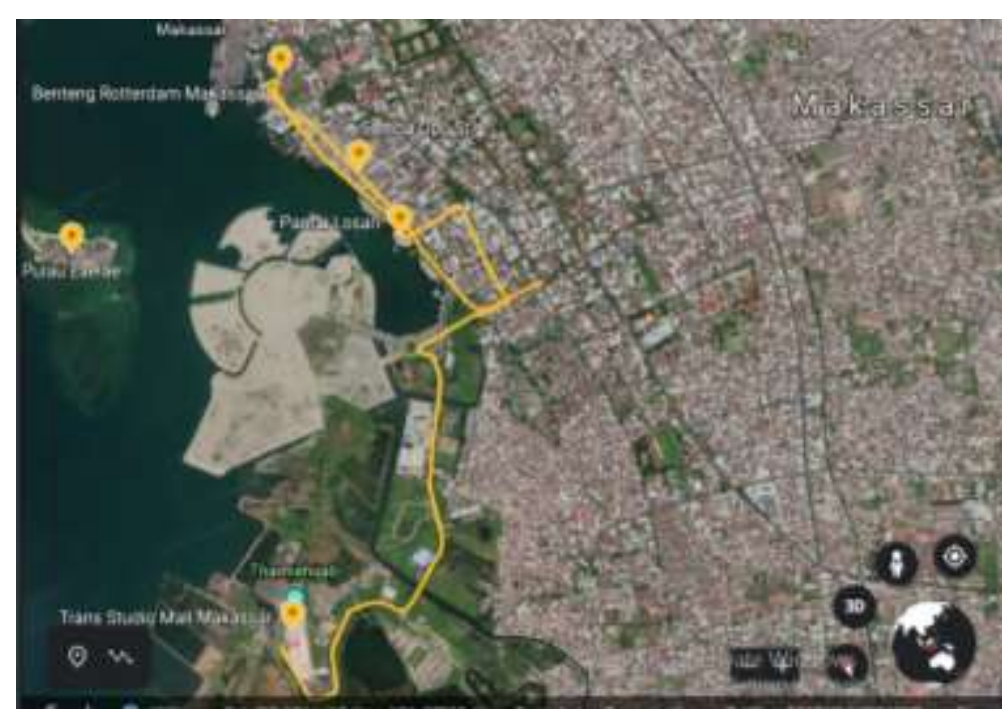

Figure 1. Map showing the pattern of spatial movements of the base site (Analysis Result, 2020)

Table 1 shows the link between one tourist point and another tourist point, can be seen from the distance, travel time, type of road, road width and transportation modes. It can be said that Losari Beach, Fort Rotterdan and Jalan Somba Opu are located in one cluster because the distance between these attractions is only 0.3 to $1 \mathrm{~km}$ and can be reached in 1 to 2 minutes. Based on the data obtained, tourists visit these three attractions using a private car or motorcycle, online motorcycle taxi or bicycle. Meanwhile, Trans Studio Mall located in the southern part of Makassar City, about $4 \mathrm{~km}$ from Jalan Somba Opu, which can be reached in four minutes by private car or motorcycle and online motorcycle taxi. Private cars and motorbikes as well as online objects are tourists' choices because these tourist destinations are not traversed by public transport routes.

Table 1. Distance and travel time between tourist destinations base site patterns (Analysis Result, 2020)

\begin{tabular}{|c|c|c|c|c|c|}
\hline $\begin{array}{c}\text { Tourist } \\
\text { attraction }\end{array}$ & Distance & $\begin{array}{l}\text { Traveling } \\
\text { Time* }\end{array}$ & Type of Road & Width of Road & $\begin{array}{c}\text { Modes of } \\
\text { Transportation }\end{array}$ \\
\hline Anjungan & & & & & Private cars \\
\hline $\begin{array}{c}\text { Pantai } \\
\text { Losari-Fort } \\
\text { Rotterdam }\end{array}$ & $1.100 \mathrm{~m}$ & $\begin{array}{c}2 \\
\text { minutes }\end{array}$ & $\begin{array}{l}\text { Jalan Penghibur } \\
\text { (arteri primer) }\end{array}$ & Jalan Penghibur (10 m) & $\begin{array}{l}\text { and } \\
\text { motorbikes, } \\
\text { online taxis, } \\
\text { bicycles }\end{array}$ \\
\hline $\begin{array}{l}\text { Fort } \\
\text { Rotterdam- } \\
\text { Jalan } \\
\text { Somba Opu }\end{array}$ & $365 \mathrm{~m}$ & 1 minute & $\begin{array}{l}\text { Jalan Penghibur } \\
\text { (arteri primer); } \\
\text { Jalan Somba Opu } \\
\text { (kolektor sekunder) }\end{array}$ & $\begin{array}{l}\text { Jalan Penghibur }(10 \mathrm{~m}) \\
\text { Jalan Somba Opu }(4 \mathrm{~m})\end{array}$ & $\begin{array}{l}\text { Private cars } \\
\text { and } \\
\text { motorbikes, } \\
\text { online taxis, } \\
\text { bicycles }\end{array}$ \\
\hline $\begin{array}{c}\text { Jalan } \\
\text { Somba } \\
\text { Opu-Trans } \\
\text { Studio Mall } \\
\text { Makassar }\end{array}$ & $4.000 \mathrm{~m}$ & $\begin{array}{c}6 \\
\text { minutes }\end{array}$ & $\begin{array}{c}\text { Jalan Somba Opu } \\
\text { (kolektor sekunder) } \\
\text { Jalan Datu Museng } \\
\text { (kolektor sekunder) } \\
\text { Jalan } \\
\text { Lamadukelleng } \\
\text { (kolektor sekunder) } \\
\text { Jalan Haji Bau } \\
\text { (arteri primer) } \\
\text { Jalan Metro } \\
\text { Tanjung Bunga } \\
\text { (arteri primer) } \\
\end{array}$ & $\begin{array}{c}\text { Jalan Somba Opu (4 m) } \\
\text { Jalan Datu Museng } \\
(8 \mathrm{~m}) \\
\text { Jalan Lamadukelleng } \\
(6 \mathrm{~m}) \\
\text { Jalan Haji Bau (10 m) } \\
\text { Jalan Metro Tanjung } \\
\text { Bunga (9 m) }\end{array}$ & $\begin{array}{c}\text { Private } \\
\text { carsand online } \\
\text { taxis }\end{array}$ \\
\hline
\end{tabular}




\subsection{Spatial Movement Pattern of Single Point}

The pattern of single point movement is the movement to a tourist destination, then back on the same route. Data shows $26.67 \%$ of tourists moving with a single point pattern. Samalona Island (16.67\%) is a favorite destination for tourists who move with this pattern. Furthermore, tourists also often choose Lae-lae Island (6.67\%) and Barrang Lompo Island (6.67\%) for oneway tourist destinations.

In general, the pattern of single point movements occurs in tourist attractions on the island. The geographical condition of the tourist attraction requires tourists to cross the ocean and spend quite a long time, which is approximately 40 minutes once boating. The character of activities carried out on the tourist island also requires energy and a longer duration, such as diving, snorkeling or swimming. Therefore, tourists also prefer to spend a full day in the tourist area, some even choose to stay overnight.

Figure 2 shows the boat path from Bangkoang Wooden Pier to tourist islands and interisland routes. Tourists who want to go to the tourist island can go along Jalan Penghibur to get to Bangkoang Wooden Pier. After that, then they can rent a boat based on their respective destination.

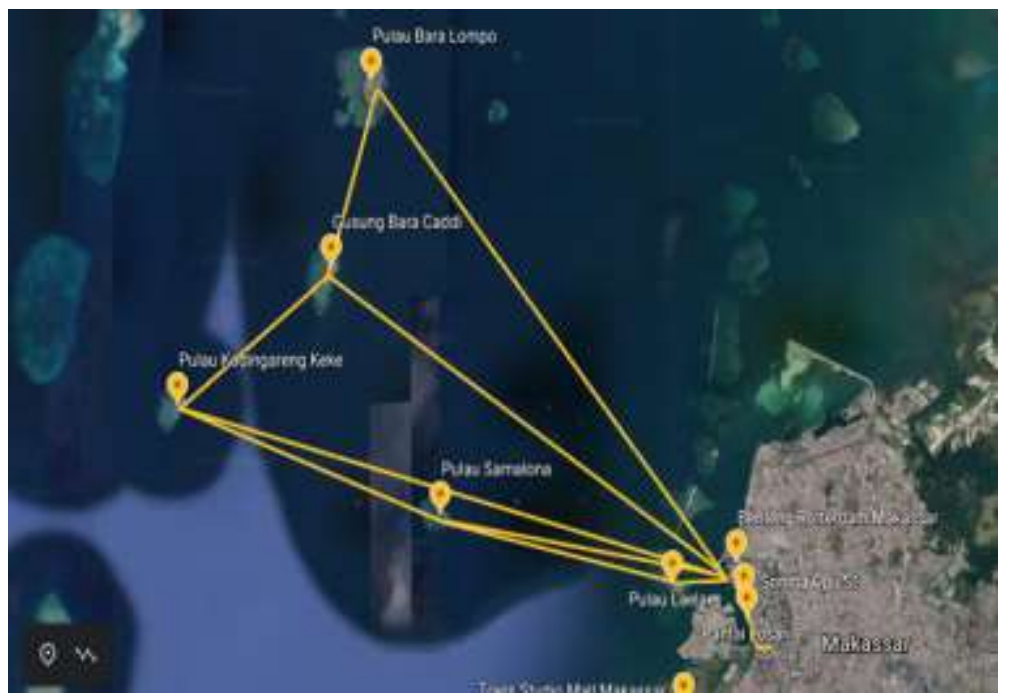

Table 2. Map showing the pattern of spatial movement of single point (Analysis Result, 2020)

Table 2 shows the distance and travel time of the boat from Bangkoang Wooden Pier to tourist islands and inter-island tours. The closest island to the mainland is Lae-lae Island with a distance of $1.2 \mathrm{~km}$ and can be reached only in a span of 10 minutes. Meanwhile, the farthest island is Kodingareng Keke Island with a distance of $13 \mathrm{~km}$ which takes 60 minutes.

Table 2. Distance and travel time between tourist destinations in single point pattern.

\begin{tabular}{ccc}
\hline Tourist Attraction & Distance & Traveling Time* \\
\hline Dermaga Kayu Bangkoang-Pulau Lae-lae & $1,2 \mathrm{~km}$ & 10 menit \\
Dermaga Kayu Bangkoang- Pulau Samalona & $6,6 \mathrm{~km}$ & 40 menit \\
Dermaga Kayu Bangkoang- Pulau Kodingareng Keke & $13 \mathrm{~km}$ & 60 menit \\
Dermaga Kayu Bangkoang-Pualau Barrang Caddi & $10,9 \mathrm{~km}$ & 50 menit \\
Dermaga Kayu Bangkoang-Pulau Barrang Lompo & $12,6 \mathrm{~km}$ & 60 menit \\
Pulau Lae-lae - Pulau Samalona & $5,8 \mathrm{~km}$ & 30 menit \\
Pulau Samalona - Pulau Kodingareng Keke & $6,5 \mathrm{~km}$ & 20 menit \\
Pulau Kodingareng Keke - Pulau Barrang Caddi & $4,4 \mathrm{~km}$ & 30 menit \\
Pulau Barrang Caddi - Pulau Barrang Lompo & $4 \mathrm{~km}$ & 15 menit
\end{tabular}




\subsection{Spatial Movement Pattern of Stop Over}

Spatial movement pattern stop over refers to movement where tourists stop by a few secondary destinations before they reach the main destination. The data shows that $13.33 \%$ of respondents engaged in a stopover movement pattern during their travel. The main destinations in this pattern include Tanjung Bayang Beach (53.33\%) dan Akarena Beach (40\%). While secondary destinations include Losari Beach, Jalan Somba Opu, and Trans Studio Mall Makassar.

Beaches are one of the main destinations in stop over movement pattern. In general, tourists spend about 2 or 3 hours doing activities there. However, before reaching the main destination, tourists stop by in other destinations that have similar character. Losari Beach, Jalan Somba Opu and Trans Studio Mall Makassar are destinations with passive activities, such as sightseeing, eating and shopping.

Beside tourism activities, tourists also visit these places to shop for necessities used at the beach. Tourists usually spend about 1 or 2 hours in these secondary destinations.Figure 3 shows stop over spatial movement pattern. From the map, it can be seen that the main tourist destination are Akkarena Beach and Tanjung Bayang Beach located in south of Makassar. However, tourists that plan to visit Losari Beach and Jalan Somba Opu might first travel through Jalan Haji Bau and Jalan Pengibur in the north then enter Jalan Metro Tanjung Bunga. For tourists that wish to stop by Trans Studio Mall, they can directly drive to Jalan Metro Tanjung Bunga.

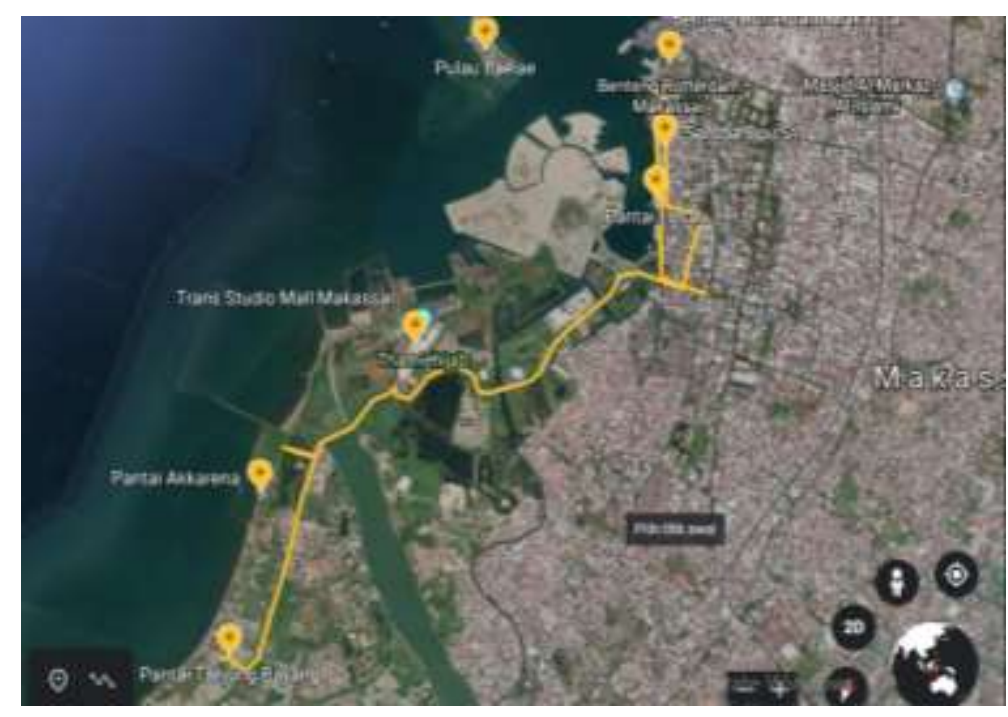

Figure 3. Map showing stop over spatial movement pattern (Analysis Result, 2020)

Table 3 shows the condition of transportation that connect tourism points in stop over movement pattern. There are two zones namely, north zone which includes secondary destinations such as Losari Beach and Somba Opu, and south zone that includes Trans Studio Mall as secondary destination, as well as Akkarena Beach and Tanjung Bayang Beach as the main destinations. Travel time between destinations varies between 1.5 to 6 minutes. Tourists mostly depend on private transportation or online rideshare services.

Table 3. Distance and travel time between tourist destinations and stop over pattern (Analysis Result, 2020)

\begin{tabular}{cccccc}
\hline Tourist Atraction & Distance & $\begin{array}{c}\text { Traveling } \\
\text { Time* }\end{array}$ & Type of Road & Width of Road & $\begin{array}{c}\text { Transportation } \\
\text { Mode }\end{array}$ \\
\hline $\begin{array}{c}\text { Anjungan Pantai } \\
\text { Losari-Jalan } \\
\text { Somba Opu }\end{array}$ & $886 \mathrm{~m}$ & 1,5 menit & Jalan Penghibur & Jalan Penghibur & $\begin{array}{c}\text { Private cars and } \\
\text { motorbikes, } \\
\text { online taxis, } \\
\text { bicycles }\end{array}$
\end{tabular}




\begin{tabular}{|c|c|c|c|c|c|}
\hline Tourist Atraction & Distance & $\begin{array}{l}\text { Traveling } \\
\text { Time* }\end{array}$ & Type of Road & Width of Road & $\begin{array}{c}\text { Transportation } \\
\text { Mode }\end{array}$ \\
\hline \multirow{6}{*}{$\begin{array}{c}\text { Jalan Somba } \\
\text { Opu-Trans } \\
\text { Studio Mall } \\
\text { Makassar }\end{array}$} & \multirow{6}{*}{$4.000 \mathrm{~m}$} & \multirow{6}{*}{6 menit } & $\begin{array}{c}\text { Jalan Somba Opu } \\
\text { (kolektor } \\
\text { sekunder) }\end{array}$ & $\begin{array}{c}\text { Jalan Somba Opu } \\
\qquad(4 \mathrm{~m})\end{array}$ & \multirow{6}{*}{$\begin{array}{l}\text { Private cars and } \\
\text { motorbikes, } \\
\text { online taxis }\end{array}$} \\
\hline & & & $\begin{array}{c}\text { Jalan Datu } \\
\text { Museng (kolektor } \\
\text { sekunder) }\end{array}$ & $\begin{array}{c}\text { Jalan Datu } \\
\text { Museng }(8 \mathrm{~m})\end{array}$ & \\
\hline & & & \multirow{2}{*}{$\begin{array}{c}\text { Jalan } \\
\text { Lamadukelleng } \\
\text { (kolektor } \\
\text { sekunder) }\end{array}$} & $\begin{array}{c}\text { Jalan } \\
\text { Lamadukelleng (6 } \\
\mathrm{m})\end{array}$ & \\
\hline & & & & Jalan Haji Bau (10 & \\
\hline & & & $\begin{array}{l}\text { Jalan Haji Bau } \\
\text { (arteri primer) }\end{array}$ & $\begin{array}{c}\mathrm{m}) \\
\text { Jalan Metro }\end{array}$ & \\
\hline & & & $\begin{array}{c}\text { Jalan Metro } \\
\text { Tanjung Bunga } \\
\text { (arteri primer) }\end{array}$ & $\begin{array}{c}\text { Tanjung Bunga (9 } \\
\text { m) }\end{array}$ & \\
\hline $\begin{array}{c}\text { Trans Studio } \\
\text { Mall- Pantai } \\
\text { Akkarena }\end{array}$ & $1.200 \mathrm{~m}$ & 2 menit & $\begin{array}{l}\text { Jalan Metro } \\
\text { Tanjung Bunga } \\
\text { (arteri primer) }\end{array}$ & $\begin{array}{c}\text { Jalan Metro } \\
\text { Tanjung Bunga (9 } \\
\text { m) }\end{array}$ & $\begin{array}{c}\text { Private cars and } \\
\text { motorbikes, } \\
\text { online taxis }\end{array}$ \\
\hline $\begin{array}{c}\text { Trans Studio } \\
\text { Mall- Pantai } \\
\text { Tanjung Bayang }\end{array}$ & $2.700 \mathrm{~m}$ & 4 menit & $\begin{array}{l}\text { Jalan Metro } \\
\text { Tanjung Bunga } \\
\text { (arteri primer) }\end{array}$ & $\begin{array}{c}\text { Jalan Metro } \\
\text { Tanjung Bunga (9 } \\
\text { m) }\end{array}$ & $\begin{array}{c}\text { Private cars and } \\
\text { motorbikes, } \\
\text { online taxis }\end{array}$ \\
\hline
\end{tabular}

* calculated using a private car with a speed of $40 \mathrm{~km} /$ hour, in smooth road conditions.

\subsection{Tourists Attractions Travel Route Instructions of Coastal Area and Small Island In Makassar}

According to the analysis, it is found that tourist movement creates a branched pattern. In other words, both base point and stop over allow tourists to visit several attractions in one day. It can also be seen from the map that circulation lane that links one tourist attraction to another creates a linear line, which means that there is a short distance between one destination to another. However, this potential is not supported by an adequate connectivity, making tourists to be mostly dependent on private transportation to move from one place to another. This might contribute to heavy traffic and tourists might skip some attractions in between tourism area. This might also lead to very little chance for tourists to be more adventurous and experiencing the sense of place from the unique coastal area because of the fast travel period.

Connector or link between attractions does not only include the physical track in traveling between one place to another, but also the experience of activities that have nautical element. The attractions explored in this study have a strong nautical element. Oceanic panorama is the main attraction feature in $80 \%$ of tourist attractions. However, the feature and activities offered in those attractions tend to more homogenous and monotone. Therefore, tourists usually only visit two or three attractions in their travel and pass on other attractions.

It is important to provide a travel route for tourism in coastal area and small islands. This route might include a one-day trip. This travel route can only be done in coastal area and 52 small islands as according to the analysis, tourists travel pattern in small islands is single $\mathrm{pc}_{\ldots . . .}$, where tourists only visit one attraction.

There are two alternative routes in coastal area. The first alternative starts from attraction in Jalan Penghibur and its surrounding and then to another attraction in Jalan Metro Tanjung Bunga. Therefore, alternative route 1 can be arranged as follows: Benteng Fort RotterdamAnjungan Pantai Losari- Jalan Somba Opu - Pantai Akkarena/Pantai Tanjung Bayang- Trans 
Studio Mall. The second alternative route is the reversed of the first route. The second alternative route starts from Jalan Metro Tanjung Bunga and ends at tourists spots in Jalan Penghibur. The alternative route 2 includes: Pantai Akkarena/Pantai Tanjung Bayang-Trans Studio Mall- Benteng Fort Rotterdam-Anjungan Pantai Losari-Jalan Somba Opu.

\section{Conclusion}

The study found that there are some trends of tourists' movements in Makassar coastal area. The majority of tourists, which is $30 \%$ of them have spatial base site patterns in their travel to attractions such as Benteng Fort Rotterdam (30,33\%) and Losari Beach (30\%).

Another pattern used by tourists in their travel in coastal area is the spatial single point. There are $26,67 \%$ of tourists use this pattern to visit some islands. This pattern is preferred as travel period to these places tend to be longer to stop over in another attractions.

Another pattern is the stop over. It is shown that 13,33\% percent of respondents tend to use this pattern to visit attractions such as Tanjung Bayang and Akkarena. There attractions tend to be more challenging. Therefore, tourists tend to stop over some places that provide some equipment that will be used in the main destinations.

Based on the three dominant patterns of tourist movement in coastal area and small islands in Makassar, there are two alternative routes, including alternative route 1: Benteng Fort Rotterdam-Anjungan Pantai Losari- Jalan Somba Opu - Pantai Akkarena/Pantai Tanjung Bayang- Trans Studio Mall. On the other hand, alternative route 2 is the reversed version of route 1. Alternative route 2 starts at tourists' attraction in Jalan Metro Tanjung Bunga and ends at tourist attraction in Jalan Penghibur. Alternative route 2 includes: Pantai Akkarena/Pantai Tanjung Bayang-Trans Studio Mall- Benteng Fort Rotterdam-Anjungan Pantai Losari-Jalan Somba Opu. These routes provide instructions for travel route in between tourist attractions in coastal area in Makasar. Meanwhile, route instructions for small islands only consists of single point, where tourists are offered a one-day trip, as their location is farther than other attractions that leads to longer travel period.

\section{References}

Cohen, E. (1972). Who is a Tourist? A Conceptual Clarification. The Sociological Review, Vol. 22 (4), halaman 527-555.

Cohen, L., Manion, L., dan Morrison, K (2007). Research Methods in Education. 6th ed., London: Roustledge.

Crompton, J. L. (1979) Motivations for Pleasure Vacation. Annals of Tourism Research, Vol. 6, Issue 4, pp. 408-424.

Dann, G. M. S. (1981) Tourist Motivation: An Appraisal. Annals of Research, Vol. 8, Issue 2, pp. 187219.

Hesna, Y., Suraji, A., Istijono, B., Hidayat, B., dan Ophyandri, T. (2016). Kajian Kapasitas Infrastruktur: Suatu Upaya Peningkatan Pariwisata Sumatera Barat. Simposium I Jaringan Perguruan Tinggi untuk Pembanugunan Infrastruktur Indonesia, pp. 296-300.

Isdarmanto. (2017). Dadar-dasar Kepariwisataan dan Pengelolaan Destinasi Pariwisata. Yogyakarta: Penerbit Gerbang Media Aksara dan Sekolah Tinggi Pariwisata Ambarukmo.

Iso-Ahola, S. E. (1980). The Social Psychology of Leisure and Recreation. Debuque, Iowa: W. C. Brown Co. Publisher.

Lau, G., dan McKrecher, B. (2006). Mapping Tourist Movement Patterns: GIS Approach. Journal of Tourism and Hospitality Research. 7(1), pp. 39-49.

Mathieson, A., dan Wall, G. (1982). Tourism Economic, Physical and Social Impacts. New York: Jhon Wiley\&Sons.

Pearce, P. L., dan Lee, Uk-II. (2005). Developing the Travel Career Approach to Tourist Motivation. Journal of Trafel Research, 43(3), pp. 226-237.

Pitana, I. G., dan Gayatri, P. G. (2005). Sosiologi Pariwisata. Yogyakarta: Penerbit Andi.

Peraturan Menteri Pariwisata Republik Indonesia Nomor 13 Tahun 2018 tentang Rencana Strategis Kementrian Pariwisata Tahun 2018-2019.

Plog, S. (2001). Why Destination Areas Rise and Fall in Popularity: an Update of a Cornell Quarterly Classic. The Cornell Hotel and Restaurant Administration Quarterly, 42(3), pp. 13-24.

Sofi, C., dan Susilowati, M. H. D. (2017). Faktor Pengaruh Pola Pergerakan Wisatawan di Kota dan Kabupaten Tegal. Prosiding 8th Industrial Research Workshop and National Seminar, Politeknik 
Negeri Bandung.

Sukmaratri, M. (2018) Kajian Pola Pergerakan Wisatawan di Daya Tarik Wisata Alam Kabupaten Malang. Jurnal Pariwisata Pesona, 03(1), pp. 33-45.

Suwena, I. K., dan Widyatmaja, I. G. N. (2017). Pengetahuan Dasar Ilmu Pariwisata. Denpasar: Pustaka Larasan.

Wasilah, dan Hildayanti, A. (2019). Karakteristik Pola Pergerakan Wisatawan di Kawasan Pantai Losari. Prosiding Seminar Nasional "Kearifan Lokal dalam Kbeberagaman untuk Pembangunan Indonesia, Universitas Sumatera Utara, pp. 51-58.

Widyastuti, H., Marsoyo, A., dan Setiawan, B. (2019). Analisis Konektivitas Antar Destinasi Pariwisata Pantai di Daerah Istimewa Yogyakarta. Jurnal Pembangunan Wilayah dan Partisipatif REGION., 14(1), pp. 1-12. 